\title{
HUBUNGAN ANTARA LINGKAR PINGGANG DENGAN KADAR ALBUMIN URIN PRIA DEWASA DENGAN OBESITAS SENTRAL
}

\author{
${ }^{1}$ Christie Endrio Biasa \\ ${ }^{2}$ Emma Sy. Moeis \\ ${ }^{2}$ B. J. Waleleng
}

\author{
${ }^{1}$ Kandidat Skripsi Fakultas Kedokteran Universitas Sam Ratulangi Manado \\ ${ }^{2}$ Bagian Ilmu Penyakit Dalam Fakultas Kedokteran Universitas Sam Ratulangi \\ Email: biasaendrio@gmail.com
}

\begin{abstract}
Obesity is an abnormal accumulation of body fat in proportion to body size. Central obesity is a major problem in clinical and public health. Central obesity is closely related to metabolic risk factors such as insulin-resistant, hypertension, and dyslipidemia. Obesity can lead to functional and structural changes in the kidneys. Reduced insulin sensitivity is the most important link between obesity and other metabolic complications cause kidney injury. Insulin also increases the effect of angiotensin II on mesangial cells, thus contributing to hypertension, increased intraglomerular pressure, exacerbation of proteinuria, intrarenal induction of inflammatory cytokines and growth factors and apoptosis. Microalbuminuria is one of the first indicators of kidney abnormalities and has been used to detect problems in kidney function. Methods: this study uses an analytical method with cross-sectional study. By looking at the relationship betwen urinary albumin with waist circumference in men with central obesity. Results: respondents waist circumference (central obesity with waist circumference $>90 \mathrm{~cm}$ ) with a urine albumin levels. 30 samples consisting of students and staff in the Faculty of Medicine Unsrat. This research was carried out not by checking the dipstick albumin as less sensitive, but using the ratio of albumin to creatinine examination. The results showed no significant association between waist circumference and urinary albumin levels. Conclusion: although the results of the study showed no significant association between waist circumference and levels of albuminuria, but not eliminate the risk of central obesity to kidney disorders.
\end{abstract}

Keywords: obesity, central obesity, urine albumin levels.

\begin{abstract}
Abstrak: Obesitas adalah akumulasi abnormal lemak tubuh dalam proporsi ukuran tubuh. Obesitas sentral adalah masalah utama secara klinik dan kesehatan masyarakat. Obesitas sentral sangat berhubungan dengan faktor-faktor resiko metabolik seperti resitensi insulin, hipertensi, dan dislipidemia. Obesitas dapat menyebabkan perubahan fungsional dan struktural pada ginjal. Sensitivitas insulin berkurang merupakan rantai penghubung yang paling penting antara obesitas dan komplikasi metabolik lainnya menyebabkan cedera ginjal. Insulin juga meningkatkan efek angiotensin II pada sel mesangial, sehingga memberikan kontribusi untuk hipertensi, peningkatan tekanan intraglomerular, eksaserbasi proteinuria, induksi sitokin inflamasi intrarenal dan faktor-faktor pertumbuhan dan apoptosis. Mikroalbuminuria adalah salah satu indikator pertama dari abnormalitas ginjal dan telah digunakan untuk mendeteksi masalah pada fungsi ginjal. Metode: penelitian ini menggunakan metode analitik dengan studi cross-sectional. Dengan melihat hubungan kadar albumin urin dengan lingkar pinggang pada pria dengan obesitas sentral. Hasil: lingkar pinggang responden (obesitas sentral dengan lingkar pinggang $>90 \mathrm{~cm}$ ) dengan kadar albumin urine. 30 sampel yang terdiri dari mahasiswa dan pegawai di Fakultas Kedokteran Unsrat. Penelitian ini dilakukan bukan dengan pemeriksaan dipstick albumin karena kurang sensitif, tapi menggunakan pemeriksaan rasio albumin terhadap kreatinin. Hasil yang diperoleh menunjukkan tidak ada hubungan yang signifikan antara lingkar pinggang dengan kadar albumin urine. Simpulan: walaupun hasil penelitian tidak menunjukkan adanya hubungan signifikan antara lingkar pinggang dengan kadar albuminuria, namun tidak menghilangkan resiko obesitas sentral terhadap gangguan ginjal.
\end{abstract}

Kata kunci: obesitas, obesitas sentral, kadar albumin urine. 
Obesitas adalah akumulasi abnormal lemak tubuh dalam proporsi ukuran tubuh. Berat badan berlebihan memiliki proporsi lemak tubuh yang sedang antara normal dan obesitas. Idealnya, sistem klasifikasi obesitas akan didasarkan pada pengukuran praktis lemak tubuh yang bisa dilakukan, yang secara akurat akan memprediksi risiko penyakit. ${ }^{1}$

Obesitas sentral adalah masalah utama secara klinik dan kesehatan masyarakat. Telah dibuktikan bahwa pengukuran obesitas sentral berhubungan dengan faktor-faktor resiko metabolik dibandingkan dengan pengukuran Indeks Massa Tubuh (IMT). Sejumlah studi menunjukkan bahwa obesitas sentral merupakan faktor resiko independen untuk diabetes mellitus tipe 2, dyslipidemia, hipertensi arterial sistemik, dan penyakit arteri coroner. $^{1,2}$

Peningkatan berat badan dan obesitas sentral berhubungan dengan resistensi insulin, hipertensi, dan dislipidemia pada diabetes tipe $1 .^{1}$ Kelainan metabolik ini merupakan faktor resiko penyakit ginjal pada populasi umum. ${ }^{2}$

Sensitivitas insulin berkurang merupakan rantai penghubung yang paling penting antara obesitas dan komplikasi metabolik lainnya menyebabkan cedera ginjal. Insulin mengganggu di beberapa titik di reninangiotensin-aldosteron sistem sistemik. Insulin juga meningkatkan efek angiotensin II pada sel mesangial, sehingga memberikan kontribusi untuk hipertensi, peningkatan tekanan intraglomerular, eksaserbasi proteinuria, induksi sitokin inflamasi intrarenal dan faktor-faktor pertumbuhan dan apoptosis. ${ }^{3,4}$

Jalan lain obesitas dapat menyebabkan albuminuria adalah melalui peranan adiposit. Adiposit sendiri menyebabkan kerusakan sel ginjal melalui beberapa cara: (1) Adiposit memiliki sistem renin angiotensin (RAS) sendiri yang dapat mengeluarkan mediator inflamasi seperti TNF- $\alpha$, IL- 6 , PAI- 1 , dan TGF- $\beta$. Faktorfaktor ini jelas terlibat dalam peran parakrin atau autokrin untuk meningkatkan fenotip inflamasi adiposit viseral, mungkin dalam bersamaan dengan infiltrasi makrofag. Semua faktor ini dapat juga bertindak secara endokrin dan menyebabkan disfungsi podo- sit dan endotel; (2) Mengeluarkan hormon tertentu seperi leptin, resistin dan adipokinektin yang secara langsung atau tidak langsung menyebabkan kerusakan ginjal. 5,6

Mikroalbuminuria adalah salah satu indikator pertama dari abnormalitas ginjal dan telah digunakan untuk mendeteksi masalah pada fungsi ginjal. ${ }^{1}$ Belum diketahui dengan jelas apakah mikroalbuminuria adalah penyebab atau konsekuensi dari kondisi seperti hipertensi dan diabetes mellitus non-insulin-dependent. Mikroalbuminuria telah diasosiasikan dengan progresi menuju penyakit ginjal kronik (PGK) dan peningkatan resiko komplikasi kardiovaskuler. $^{3}$

Obesitas dapat menyebabkan perubahan fungsional dan struktural pada ginjal, dan korelasi utama antara obesitas dan beberapa kondisi patologis telah ditunjukkan bergantung pada distribusi anatomis dari jaringan adiposa. $^{2}$

Berdasarkan fakta-fakta tersebut, penulis tertarik untuk melakukan penelitian mengenai hubungan kadar albumin urin dengan lingkar pinggang pada pria dengan obesitas sentral.

\section{METODOLOGI PENELITIAN}

Penelitian ini menggunakan metode analiti dengan studi cross sectional dengan mencari hubungan antara lingkar pinggang dengan kadar albumin urine, dengan subjek penelitian terdiri dari 30 sampel mahasiswa dan pegawai di Fakultas Kedokteran Unsrat. Penelitian ini dilaksanakan pada bulan November 2013- Desember 2013. Populasi penelitian ini adalah seluruh mahasiwa dan pegawai pria berumur 20-50 tahun.

\section{HASIL PENELITIAN DAN BAHASAN}

Penelitian ini mencari hubungan antara lingkar pinggang responden (obesitas sentral dengan lingkar pinggang $>90 \mathrm{~cm}$ ) dengan kadar albumin urine. 30 sampel yang terdiri dari mahasiswa dan pegawai di Fakultas Kedokteran Unsrat. Sampel dalam penelitian ini normal tanpa penyakit seperti hipertensi atau diabetes mellitus. Penelitian ini dilakukan bukan dengan pemeriksaan 
Biasa, Moeis, Waleleng; Hubungan antara Lingkar Pinggang...

Tabel 1. Karakteristik sampel penelitian

\begin{tabular}{lccccc}
\hline & n & Min & Maks & Rerata & SB \\
\hline Umur & 30 & 21 & 50 & 28,03 & 10,36 \\
$<30$ & 22 & 21 & 29 & 22,18 & \\
$>30$ & 8 & 35 & 50 & 45,43 & \\
Lingkar pinggang & 30 & 94 & 119 & 102,03 & 6,72 \\
$\quad<100$ & 13 & 94 & 100 & 96,8 & \\
$>100$ & 17 & 101 & 119 & 107,23 & \\
Albumin (RAKU) & 30 & 3 & 37 & 5,86 & 6,83 \\
$<30$ & 29 & 3 & 19 & 4,69 & \\
$>30$ & 1 & 37 & 37 & 37 & \\
\hline
\end{tabular}

dipstick albumin karena kurang sensitif, tapi menggunakan pemeriksaan rasio albumin terhadap kreatinin. Perbandingan ini disebut rasio albumin kreatinin urin (UACR)., Kurangnya sensitivitas berarti bahwa dipstick negatif untuk albumin atau protein tidak mengesampingkan adanya albuminuria patologis atau proteinuria. Semua bentuk proteinuria patologis cenderung dimulai dengan albuminuria. ${ }^{8,9}$

Dari Tabel 1 ditemukan bahwa rata-rata umur sampel pada penelitian ini adalah 28,03 tahun dimana umur paling muda adalah 21 tahun dan paling tua 50 tahun.

Lingkar pinggang rata-rata pada sampel adalah 102,03 $\mathrm{cm}$ sedangkan rata-rata ratio albumin kreatini urin adalah 5,86 $\mu \mathrm{g} / \mathrm{mg}$. dimana lingkar pinggang $<100 \mathrm{~cm}$ sebanyak 13 orang dan $>100 \mathrm{~cm}$ sebanyak 17 . Albumin (RAKU) pada sampel minimal $<3$ maksimal 37, dimana $<30$ sebanyak 20 orang dan $<30$ sebanyak 1 orang.

Tabel 2. Distribusi sampel penelitian berdasarkan lingkar pinggang dan kadar albumin

Albumin

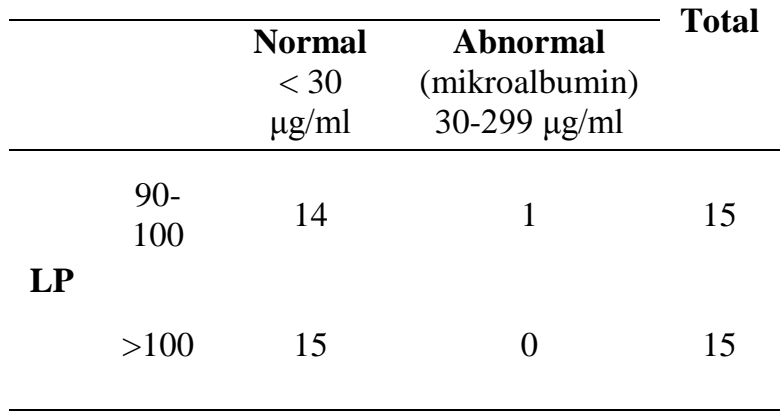

Dari Tabel 2 ditemukan bahwa pada lingkar pinggang 90-100 $\mathrm{cm}$ terdapat 1 sampel dengan nilai ratio albumin kreatinin urin abnormal sedangkan sampel dengan lingkar pinggang $>100 \mathrm{~cm}$, semuanya normal.

Nilai RP diperoleh dengan perhitungan:

$$
\begin{aligned}
R P & =\frac{A}{A+B}: \frac{C}{C+D} \\
& =\frac{14}{15}: \frac{15}{15} \\
R P & =\frac{14}{15}: 1 \\
R P & =<1
\end{aligned}
$$

Simpulan: Lingkar pinggang bukan merupakan faktor resiko terhadap albumin urine.

Tabel 3. Distribusi sampel berdasarkan usia dan RAKU

\begin{tabular}{ccc}
\hline $\begin{array}{c}\text { Usia } \\
\text { (tahun) }\end{array}$ & $\mathbf{n}$ & $\begin{array}{c}\text { RAKU } \\
(\mu \mathrm{g} / \mathrm{mg})\end{array}$ \\
\hline $20-30$ & $22(73,3 \%)$ & 4,1 \\
$31-40$ & $2(6,7 \%)$ & 2 \\
$41-50$ & $6(20,0 \%)$ & 7,3 \\
Total & $30(100 \%)$ & 13,4 \\
\hline
\end{tabular}

Dari Tabel 3, distribusi sampel terbanyak pada penelitian ini adalah pada usia 20 -30 tahun $(73,3 \%)$ dengan rata-rata ratio albumin kreatinin urin $4,1 \mu \mathrm{g} / \mathrm{mg}$. Usia 31-40 tahun sebanyak 2 sampel dengan ratarata albumin kreatinin urin $2 \mu \mathrm{g} / \mathrm{mg}$, dan usia 41-50 tahun sebanyak 6 sampel dengan ratio albumin kreatinin urin 7,3 $\mu \mathrm{g} / \mathrm{mg}$. 
Tabel 4. Hubungan Lingkar pinggang dengan RAKU

Correlations

\begin{tabular}{|c|c|c|c|c|}
\hline & & & $\begin{array}{l}\text { Lingkar } \\
\text { Pinggang }\end{array}$ & RAKU \\
\hline \multirow{6}{*}{ Spearman's rho } & \multirow{3}{*}{ Lingkar Pinggang } & Correlation Coefficient & 1.000 & -.386 \\
\hline & & Sig. (2-tailed) & 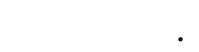 & .113 \\
\hline & & $\mathrm{N}$ & 30 & 30 \\
\hline & \multirow{3}{*}{$\begin{array}{l}\text { Rasio Albumin } \\
\text { Kreatinin Urine }\end{array}$} & Correlation Coefficient & -.386 & 1.000 \\
\hline & & Sig. (2-tailed) & .113 & \\
\hline & & $\mathrm{N}$ & 30 & 30 \\
\hline
\end{tabular}

Untuk mengetahui adanya hubungan lingkar pinggang dengan RAKU digunakan analisis bivariat Spearman's rho. Pada penelitian ini didapatkan nilai $\mathrm{p}=0,386$ dapat disimpulkan bahwa tidak ada hubungan yang signifikan antara lingkar pinggang dengan kadar albumin urine pada penelitian ini. $^{10,11}$

Dengan nilai $\mathrm{p}=0,386$ dapat disimpulkan bahwa tidak ada hubungan yang signifikan antara lingkar pinggang dengan kadar albumin urine pada penelitian ini. ${ }^{10,11}$

\section{SIMPULAN}

Dari hasil penelitian hubungan antara lingkar pinggang dengan kadar albumin urine, maka dapat disimpulkan, tidak ada hubungan yang signifikan antara lingkar pinggang dengan kadar albumin urine. Pada penelitian ini lingkar pinggang independen terhadap kadar albuminuria.

\section{DAFTAR PUSTAKA}

1. de Boer IH, Sibley SD, Kestenbaun B, Sampson JN, Young B, Cleary PA, et al. Central obesity, incident microalbuminuria, and change in creatinine clearance in the epidemiology of diabetes interventions and complications study. Journal of the American Society of Nephrology. 2009; 18: p. 235-243.

2. Ashwell, Ashwell M. Charts based on body mass index and waist-to-height ratio to assess the. The Open Obesity Journal. 2011; 3: p. 78-84.

3. Miller GW, Bruns DE, Sandberg S, Aakre
KM, McQuen MJ, Itoh Y, et al. Current issues in measurement and reporting of urinary albumin excretion. Clinical Chemistry. 2009; 55(1): p. 24-38.

4. Chandie P, Baboe F, Van Es L, Van der Vijver J, Van de Ree M, de Jonge N, et al. South Asian type 2 diabetic patients have higher incidence and faster progression of renal disease compared with Dutch European diabetic patients. Diabetes Care. 2009; 29: p. 1383-1385.

5. Mather $\mathrm{H}$, Chaturvedi $\mathrm{N}$, Kehely A. Comparison of prevalence and risk factors for microalbuminuria in south asians and europeans with type 2 diabetes mellitus. Diabet Med. 2008; 15: p. 672-677.

6. Chandie P, Vandenbroucke J, Tjandra Y, Rosendaal F, Rosman J, Geerlings W, et al. Increased end-stage diabetic nephropathy in Indo-Asian immigrants living in theNetherlands. Diabetologia. 2008; 45: p. 337-341.

7. Hsu CY, McCulloch CE, Iribarren C, Darbinian J, Go AS: Body mass index and risk for end-stage renal disease. Ann Intern Med 2009, 144:21-28.

8. WHO. Waist circumfrence and waisth-hip ratio. Report of a WHO expert consultion. World health organization.2008.

9. Fox CS, Larson MG, Leip EP, Culleton B, Wilson PW, Levy D: Predictors of newonset kidney disease in a community-based population. JAMA 2004, 291:844-850.

10. Santoso S. Statistik parametrik. Konsep dan aplikasi dengan SPSS. Elex Media Komputindo, 2010. p 79-94.

11. Santoso S. Statistik nonparametrik. Konsep dan aplikasi dengan SPSS. Elex Media Komputindo, 2011. p 219-271. 